\title{
The Bear Brook Watershed in Maine-The Second Decade
}

\section{Preface}

\author{
Ivan J. Fernandez $\cdot$ Stephen A. Norton
}

Published online: 11 June 2010

(C) Springer Science+Business Media B.V. 2010

This special issue of Environmental Monitoring and Assessment (EMA) contains ten papers that describe evidence of biogeochemical change, in a non-stationary physical and chemical climate, in a paired, forested watershed of northern New England, USA, the Bear Brook Watershed in Maine (BBWM). The initial research emphasis at BBWM was to define the terrestrial-aquatic linkages important in governing surface water response to elevated atmospheric sulfur (S) deposition. Both empirical and experimental approaches were used to understand the linkages. The research emphasis almost immediately evolved to include the biogeochemical role of nitrogen $(\mathrm{N})$, an important atmospheric pollutant, and a broadening scope of scientific objectives seeking to discover underlying mechanisms of ecosystem response to environmental change. As the paper by Norton et al. (2010) details, the historical trajectory of science is often strongly influenced by colleagues and collaborators, and the times we live in; the BBWM has been no exception.

The findings presented in this volume build on more than 140 refereed publications from the

I. J. Fernandez $(\varangle) \cdot$ S. A. Norton

University of Maine, 5722 Deering Hall, Orono, ME 04469, USA

e-mail: ivanjf@maine.edu
BBWM study published in the scientific literature. After the first decade of research (1987-1996), Norton and Fernandez (1999) edited a volume that provided insights and findings not yet reported elsewhere at that time. In 1996, no one knew how long the study would continue. It was clear that our understanding of ecological function in these forested watersheds was incomplete and required the benefit of long-term research to formulate the right questions to ask, let alone to discover their answers. At the end of the second decade (2006), we found ourselves even more convinced of the importance of long-term research and we are pleased to present the collection of papers in this second special volume. These papers provide insights on soils (SanClements et al. 2010; Amirbahman et al. 2010), precipitation and streams (Navrátil et al. 2010; Kim et al. 2010; Laudon et al. 2010; Porcal et al. 2010; Simon et al. 2010), vegetation (Elvir et al. 2010), and an update of the comparison between BBWM and the Fernow Experimental Watershed (Fernandez et al. 2010), a complementary watershed research program and long-term collaborators. Seven of the papers present data and analysis of the 20 -year period. In addition, the papers herein direct readers to many other works in the scientific literature that fill in the BBWM story.

If we are to assemble a knowledge base necessary to understand ecosystem function and assure ecosystem services in the changing physical 
and chemical climate of the twenty-first century (IPCC 2007a, b), it will be essential to maintain, and utilize insights from, long-term research. This special issue is an attempt to achieve those objectives as the BBWM project continues into its third decade of research. The need for long-term research is an increasingly common theme in scientific discourse (e.g., Janzen 2009; Richter et al. 2007), yet only time will tell if the existing programs that already enjoy lengthening long-term data sets can be maintained, and if the necessary new initiatives for studying long-term ecological processes will be supported.

As with any scientific publication, numerous people have contributed to the development of this special issue beyond the authors. We express our deep appreciation to those contributors, most notably the thoughtful reviewers of manuscripts contained in this dedicated issue of EMA. They include W. Brutsaert, B. J. Cosby, C. Cronan, K. Elliot, F. Fatemi, H. Goss, R. Hallet, A. Jenkins, D. Johnson, G. Hodgkins, P. Kram, B. Lake, M. Pierret-Neboit, S. Ohno, B. Pellerin, R. Perry, A. Reeve, D. Ross, L. Rustad, J. Saros, A. Scott, C. Spencer, and R. Wright. We also extend our appreciation to G. B. Wiersma and the staff of EMA, particularly B. van Herk, who have been extremely encouraging, helpful, and patient in the development of this special issue.

\section{References}

Amirbahman, A., Holmes, B. C., Fernandez, I. J., \& Norton, S. A. (2010) Mobilization of metals and phosphorus from intact forest soil cores by dissolved inorganic carbon. doi:10.1007/s10661-010-1522-4.

Elvir, J. A., Wiersma, G. B., Bethers, S., \& Kenlan, P. (2010) Effects of chronic ammonium sulfate treatment on the forest at the Bear Brook Watershed in Maine. doi:10.1007/s10661-010-1523-3.

Fernandez, I. J., Adams, M. B., SanClements, M. D., \& Norton, S. A. (2010) Comparing decadal responses of whole-watershed manipulations at the Bear Brook and Fernow experiments. doi:10.1007/s10661010-1524-2.
IPCC (2007a). Climate change 2007: The physical science basis. In S. Solomon, D. Qin, M. Manning, Z. Chen, M. Marquis, K. B. Averyt, et al. (eds.), Contribution of working group I to the fourth assessment report of the intergovernmental panel on climate change. Cambridge: Cambridge University Press.

IPCC (2007b). Climate change 2007: Impacts, adaptation and vulnerability. In M. L. Parry, O. F. Canziani, J. P. Palutikof, P. J. van der Linden, \& C. E. Hanson (eds.), Contribution of working group II to the fourth assessment report of the intergovernmental panel on climate change. Cambridge: Cambridge University Press.

Janzen, H. H. (2009). Long-term ecological sites: Musings on the future, as seen (dimly) from the past. Global Change Biology, 15, 2770-2778.

Kim, J.-S., Jain, S., \& Norton, S. A. (2010) Streamflow variability and hydroclimatic change at the Bear Brook Watershed in Maine (BBWM), USA. doi:10.1007/ s10661-010-1525-1.

Laudon, H. \& Norton, S. A. (2010) Drivers and evolution of episodic acidification at the Bear Brook Watershed in Maine, USA. doi:10.1007/s10661-010-1526-0.

Navrátil, T., Norton, S. A., Fernandez, I. J., \& Nelson, S. J. (2010) Twenty-year inter-annual trends and seasonal variations in precipitation and stream water chemistry at the Bear Brook Watershed in Maine, USA. doi:10.1007/s10661-010-1527-z.

Norton, S. A., \& Fernandez, I. J. (eds.) (1999). The Bear Brook Watershed in Maine-A paired watershed experiment-the first decade (1987-1997) (250 pp.). Boston: Kluwer.

Norton, S. A., Fernandez, I. J., Kahl, J. S., Rustad, L. E., Navrátil, T., \& Almquist, H. (2010) The evolution of the science of Bear Brook Watershed in Maine, USA. doi:10.1007/s10661-010-1528-y.

Porcal, P., Amirbahman, A., Kopáček, J., \& Norton, S. A. (2010) Experimental photochemical release of organically-bound aluminum and iron in three streams in Maine, USA. doi:10.1007/s10661-010-1529-x.

Richter, D. deB. Jr., Callaham, M. A., Jr., Powlson, D. S., \& Smith, P. (2007) Long-term soil experiments: Keys to managing earth's rapidly changing ecosystems. Soil Science Society of America Journal, 71, 266-279.

SanClements, M. D., Fernandez, I. J., \& Norton, S. A. (2010) Soil chemical and physical properties at the Bear Brook Watershed in Maine, USA. doi:10.1007/s10661-010-1531-3.

Simon, K. S., Chadwick, M. A., Huryn, A. D., \& Valett, M. H. (2010) Stream ecosystem response to chronic deposition of $\mathrm{N}$ and acid at the Bear Brook Watershed, Maine. doi:10.1007/s10661-010-1532-2. 